\title{
Efficiency of Microfinance Institutions in Sub - Saharan Africa: A Stochastic Frontier Approach
}

\author{
Adams Abdulai ${ }^{17}$ \\ Faculty of Commerce, Administration and Law, University of Zululand, \\ Private Bag X1001, KwaDlangezwa, 3886, South Africa. \\ boginah@yahoo.com \\ and \\ Devi Datt Tewari \\ Faculty of Commerce, Administration and Law, University of Zululand, \\ Private Bag X1001, KwaDlangezwa, 3886, South Africa. \\ DOI//http://dx.doi.org/10.4314/gjds.v13i2.7
}

\begin{abstract}
The push for microfinance institutions (MFIs) to achieve sustainability in recent years has made efficiency a prerequisite. Assessment of efficient operations of MFIs is vital for both policy and investment decision making and guaranteeing financial access to the poor. This study investigates the cost efficiency of MFIs operating in 10 Sub-Saharan Africa (SSA) countries over the period 2003-2013 and the factors that drive efficiency. The authors considered the Cobb-Douglas stochastic cost frontier model with truncated normal distribution and time variant inefficiency were estimated. The results show that MFIs are cost inefficient in their intermediation role as they currently achieve a mean cost efficiency of 40.09 percent. The main determinants of MFIs efficiency are total assets, operating expense to assets ratio, average loan balance per saver, the percentage of the female borrower and borrower per staff member. The study recommends that practitioners and managers of MFIs should improve on productivity through technical training in portfolio quality management and offer diverse financial products and services innovatively at minimised cost.
\end{abstract}

Keywords: Efficiency, Microfinance Institutions, Stochastic Frontier Analysis, Sub-Saharan Africa

17. Corresponding author: Adams Abdulai 


\section{Introduction}

The role of microfinance institutions (MFIs) in economic development has long been recognised though it only became part of the financial system in most developing countries in the early 1990s. Evidently, countries with larger microfinance sectors experience lower levels of poverty (Imai, Gaiha, Thapa \& Gupta, 2012), and yet efficient assessment of the operations of these institutions remains very low in Africa where development aid is proportionately large (Honohan, 2008). Ineffective MFIs are a major constraint on the development of the microfinance industry (Helms, 2006). The efficient supply of financial services to the poor is crucial in ensuring balanced national development and this is attainable through efficient institutions.

The efficiency and sustainability of MFIs have become key concerns in recent times following increased donor accountability, the need for regulation, increased investor interest and market-driven boards of directors who demand strong financial performance. Efficient MFIs should be able to deliver services effectively at minimised costs. However, the average cost per borrower (72 dollars) remains higher in Africa compared to other continents (Lafuorcade, Isern, Mwangi \& Brown, 2005). The microfinance industry has come under scrutiny following numerous studies that tend to show limited impacts of microfinance on development outcomes (Bataman, 2011; Bhatt \& Tang, 2001). Bhatt \& Tang (2001) found that most microfinance programmes had difficulty in sustaining their operations in the absence of grants, external funding, and subsidies, signifying inefficiency in their operations. MFIs striving to achieve sustainability through commercialisation suggest that subsidisation may have compromised the efficiency of these institutions. As Conning (1999) noted, subsidies may keep inefficient institutions alive, but only in the short term.

Although, majority (83 percent) of MFIs are not efficient, the exact level of inefficiency and ways to improve operations remain largely unexplored. To date, a little systematic study has been done to measure the efficiency level of MFIs, particularly in SSA. Only a few studies (Abate, Borzaga, \& Getnet, 2014; Segun \& Anjugan, 2013; Oteng-Abayie, Amanor, \& Frimpong, 2011) have explored this subject matter in Africa. While the work of Abate et al. (2014) is a field-based report which focused on MFIs only in Ethiopia, that of Oteng-Abayie et al. (2011) is based on sampled MFIs in Ghana. Thus, they are country specific case studies that do not give a bigger picture of the microfinance industry in the region. A cross country analysis is relevant in pulling lessons learned together to support the scaling up of microfinance interventions in the region. Moreover, the study by Abate et al. (2014) relied on data collected for only a year but analysing cost efficiency within a panel data framework could yield much richer results for policy considerations. 
Efficiency is critical for MFIs to remain competitive and responsive to clients' needs. This study examines empirically the cost efficiency of MFIs in SSA and the factors that influence their efficiency levels using the Stochastic Frontier Approach (SFA). Our study differed from previous studies in that it analyses for the first time a large number of input and output variables in the cost frontier using recent panel data with the application of the time-dependent stochastic frontier model. The study adds insights to the existing literature by considering the effects of various institutional factors on efficiency in our analysis. The rest of the study is organised as follows: Section two sets out the relevant literature review on efficiency. Section three presents empirical methods and data. Section four discusses the empirical results followed by summary and conclusion in section five.

\section{Literature Review}

\section{Concept of Efficiency and its Relation to Outreach and Sustainability}

The concept of efficiency is at the core of economic theory as firms try to optimize production by making decisions that are geared toward the maximization of certain goals (profit, scale or efficiency). The efficiency of a firm has several dimensions. Farrell (1957) discusses the concept of economic efficiency to compose of two parts: technical and allocative. Technical efficiency is the firm's ability to maximize outputs from a given set of inputs while allocative efficiency depicts the use of inputs in optimal proportions given their relative prices. In the context of microfinance, Balkenhol (2007) defined technical efficiency as the optimal combination of staff time, assets and subsidies (inputs) to produce a maximum number of loans, attain financial self-sufficiency and poverty outreach (outputs). Another, commonly used concept is cost efficiency which describes the minimum cost incurred by a firm to produce some level of output given input prices. Therefore, efficiency measurements that show the scope for improved performance are useful for policy formulation and analysis and could help management to invest in productive activities at minimum costs.

Several empirical studies examined the relationship between microfinance outreach, sustainability, and efficiency. Outreach is one of the dual goals of MFIs and it can be defined as the number of poor clients reached with financial services by an institution. Extending financial services to underserved populations often comes at a cost with likely impact on operations. Adhikary \& Papachristou (2014) analysed the relations between financial performance and outreach of MFIs in South Asia for the period 20032009 using the random effects and generalised method of moment methods. They found MFIs' outreach to be positively related to profitability and efficiency. Similarly, Ayayi \& Sene (2010) reported that client outreach has positive impacts on the attainment 
of financial sustainability. In their study of 217 MFIs across 101 countries, the authors further noted that financial sustainability is enhanced by high-quality credit portfolio, application of high-interest rate and sound management. However, Hermes, Lensink \& Meesters (2009) using the stochastic frontier analysis (SFA) approach found MFIs outreach to be negatively related to efficiency. Thus, institutions with lower average loan balances and more women borrowers were found to be less efficient. This is corroborated by Abate et al. (2014) who found evidence of a trade-off between outreach and cost efficiency in MFIs. The authors revealed a greater cost efficiency gap between specialised MFIs and financial cooperatives in their performances with cooperatives showing better cost containment, a situation they attributed to the effective use of social collaterals in contract enforcement.

Other efficiency studies on microfinance have followed the data envelopment analysis (DEA) approach. Nawaz (2009) examined the role of subsidies in microfinance efficiency and reported that subsidies only play a marginal role in MFIs financial efficiency but that a trade-off exists between outreach and financial efficiency. This suggests that MFIs that focus on outreach are less efficient, and lending to women in the absence of subsidies is also inefficient. Similarly, Glass, McKillop, \& Rasaratnam (2009) investigated how environmental factors influence performance of the Irish League of Credit Unions (ICUs). The results show that only seven percent of the institutions were technically efficient while the remaining 93 percent operated at various levels of inefficiency. The bestpracticed firms were observed to have few bad debts and designated as 'industrial or associational Credit Unions' and informational advantages arising from common bonds facilitated lending decisions. Amersdorffer, Buchenrieder, Bokusheva \& Wolz (2015) analysed the performance of 15 Agricultural Credit Cooperatives (ACCs) in Bulgaria using data for the period 2000 to 2009 based on a case study. The authors developed a new analytical model for DEA based on the Social Performance Indicator (SPI) audit tool which enabled them to evaluate the quality of social networks and client benefits within the framework of efficiency analysis. The study revealed that only ACCs which perform well financially could be ranked higher in the social output specification but that financial performers do not necessarily make the best social performers. High external capital costs were found to have adverse effects on the frontiers which impeded the growth of the institutions.

Bos \& Millone (2014) used different business models to estimate the efficiency of MFIs taking into account the multiple dimensions of output. Their results show that MFIs with significant depth of outreach achieve allocative efficiency. Thus, output mix strongly influences the efficient performance of MFIs negatively, causing some MFIs to shift away from their business models. Furthermore, a significant trade-off exists 
between MFIs financial and social performance though the level of effect varies with institutional type.

\section{Determinants of Microfinance Institutions Efficiency}

MFIs have been faced with growing competition, both from within and outside the industry but will presumably remain in business if they operate efficiently (Rhyne \& Otero, 2006). Competition in the industry is growing and this could lead to an efficient expansion of microfinance products to clients. At the same time, lending to the poor could come at the expense of attaining efficiency. Recent transformations in microfinance towards financial policy regulations have implications for competition and efficiency. Regulatory policies aimed at enhancing competition can exert competitive pressure and create incentives for improvements in efficiency, which may enhance financial stability (Tabak, Fazio, \& Cajueiro, 2012). Institutional environments and regulatory structures have been found to affect the efficiency of banking operations in different ways and in different country contexts (Barth, Lin, Ma, Saede \& Song, 2013). In the case of emerging markets, Rojas-Suarez (2007) observed that the combination of market power and industry concentration could hinder financial deepening and efficiency gains. Conversely, Berger \& DeYoung (1997) find that competition may adversely affect efficiency due to poor management in client screening, monitoring and the accumulation of non-performing loans. Similarly, Guha \& Chowdhury (2013) examined the effects of microfinance competition and default to show that doubledipping $^{18}$ occurs at equilibrium for profit oriented MFIs which naturally leads to default and inefficiency.

Banking sector studies have revealed numerous determinants of efficiency in the past, such as high capital to assets ratio, the age of bank, number of branches, ownership status, managerial control, organisational structure, economic performance and location (Valenverde et al., 2007; Gutierrez-Nieto, Serrano-Cinca, \& Molinero, 2007). These factors are applicable to the microfinance sector. Theoretical and empirical evidence shows that the type of MFI influences efficiency. Mersland \& Strom (2009) show that non-governmental organizations (NGOs) and credit cooperatives are more cost efficient due to market contracts (group lending) which help overcome information asymmetries. Similarly, Haq, Skully \& Pathan (2010) found NGOs more efficient in transforming inputs into outputs (production approach) while banks exhibited greater efficiency in funds mediation between savers and borrowers (intermediation approach). This suggests that model specification could have implications for measured efficiency. Gutierrez-Nieto et al. (2007) show that location and NGO status influence MFI efficiency. Lafourcade et al. (2005) reported that formal MFIs are more efficient than semi-formal

18. A situation where borrowers take multiple loans from different sources and find it difficult to repay. 
MFIs. However, among the formal MFIs, cooperatives were the least efficient. Similarly, Hassan \& Sanchez (2009) found higher technical efficiencies with formal MFIs (Banks and Credit Unions) than non-formal MFIs (non-profit organizations and NBFIs). The difference between these last two studies is that while the latter explored the source of inefficiency which was due to pure technical rather than scale efficiency, the former did not explore the source of inefficiency.

Oteng-Abayie et al. (2011) analysed the determinants of MFI economic efficiency in Ghana using the Cobb-Douglas stochastic frontier model for the period 2007-2010. They found the institutions highly inefficient with an average economic efficiency of 56.29 percent. Moreover, the age of institution, cost per borrower and savings indicators of outreach and productivity are significant drivers of economic efficiency. Similarly, Singdhu, Goyaldu \& Sharmadu (2013) found MFIs technically inefficient (40.6 percent) using Tobin's regression and correlation analysis for the period 2005-2009. Total assets, location, and borrower per staff were found to be significant determinants of technical efficiency. Previously, Nghiem, Coelli, \& Rao (2006) investigated both technical and scale efficiency of 46 microfinance schemes in Vietnam to show that they attained average technical efficiency of 80 percent. Age and location of schemes were significant factors that influence efficiency.

\section{Methodology}

\section{Theoretical Stochastic Frontier Model}

The assumption which underpins the measurement of efficiency is the existence of a gap between the observed performance of a firm and its potential level. Technical efficiency is therefore measured as the ratio of actual output to the potential output. Various measurement approaches have been employed in efficiency analysis which includes: (1) the tick frontier approach (2) the distribution-free approach (3) DEA and (4) SFA. Each approach has its own strengths and weaknesses and the debate on which approach is superior remains inconclusive in the literature despite the wider application for DEA and SFA. One key advantage of DEA is that it can accommodate multiple inputs and outputs and allow technological change measurement. However, downward biassed efficiency estimates with the potential to eliminate efficient firms from the comparisons have been noted as a key limitation. Also, satisfactory management of noisy data (Worthington, 2000), including unbalanced panels, remains a challenge. However, bootstrapping approaches have been developed over the years to overcome these limitations [see for example Wilson (2008); Simar \& Wilson $(1998,2000)]$. The SFA methodology was first proposed and developed independently by Aigner, Lovell \& Schmidt (1977) and Meeusen and van den Broeck (1977) for cross-sectional data and later 
extended by (Pitt \& Lee, 1981; Seale, 1990) for panel data. One limitation of this approach is that the estimation procedure is very cumbersome and it has the tendency to produce different results (Schmidt \& Sickles, 1984) unless care is taken. Also, assumptions must be made of the specific functional form and distribution of the inefficiency before estimation can be done. Despite these, the approach can handle outliers and noisy date efficiently. It also enables statistical tests of hypothesis to be performed. Hence, the choice of SFA over DEA in this study. The stochastic frontier can be modelled in terms of either production or cost function. However, estimation of cost functions has gained more prominence in recent times since minimisation of industry cost is critical to MFI success. Following previous work by Hermes, Lensink \& Meesters (2011) and OtengAbayie et al. (2011) the present study estimates cost function following the Battese \& Coelli (1995) family models. The theoretical cost model specified for panel data is generally given as:

$$
\operatorname{In} C_{i, t}=C\left(y_{i, t}, w_{i, t}, q_{i, t} ; \beta\right)+u_{i, t}+v_{i, t}
$$

where $C_{i, t}$ is total cost faced by the MFI with $(i, t)$ representing the cross sectional and time dimensions of the data and $C\left(y_{i, t}, w_{i, t}, q_{i, t} ; \beta\right)$ is the cost frontier. $y_{i, t}$ is the logarithm of output. $W_{i, t}$ is the vector of logarithm of input prices. $q_{i, t}$ are MFI specific control variables. $\beta$ is a vector of all parameters to be estimated. $u_{i, t}$ captures cost inefficiency and is independent and identically distributed with a truncated normal distribution. $v_{i, t}$ captures measurement errors, omitted variables and random effects and is distributed as a standard normal variable. Both $u_{i, t}$ and $v_{i, t}$ are time and MFI specific and are represented as $v_{i, t} \sim \operatorname{iid} N\left(\mathrm{O}, \mathrm{s}^{2}\right)$ and $N_{\sim}^{+}\left(, \mathrm{s}_{\mathrm{u}}^{2}\right)$.

The stochastic inefficiency term is generally defined as:

$$
m_{i, t}=\delta_{0}+\sum_{n} \delta n z_{n, i, t}
$$

where $z$ denotes the vector of $n$ variables that determine the inefficiency of MFI $i$ at time $t$, and the deltas are the coefficients to be estimated. Considering the various distributional forms that the inefficiency term assumes, our study follows the normal truncated distribution as it is more flexible and allows both the shape and slope of the cost function to vary independently. The expected value of the inefficiency of each MFI at a given time period is conditional on the composed error term as defined by Jondrow, Lovell, Materov \& Schmidt (1982). The standard estimator is as follows:

$$
E\lfloor u / \varepsilon\rfloor=\frac{\sigma \lambda}{1+\lambda^{2}}\left[\frac{\varphi(w)}{1-\varphi(w)}-w\right], \varepsilon=v+u, w=S \varepsilon \lambda / \sigma
$$

Since the inefficiency term $\left(m_{i, \mathrm{t}}\right)$ cannot be estimated directly from the sample, this approach serves as an indirect estimator for computing it. The inefficiency component 
is retrieved from the composite error term for the cost function estimation for each MFI. The inefficiency level for an individual MFI is computed as:

$$
T E_{i t}=\exp \left(-U_{i t}\right)
$$

where $U_{i, t}$ denotes the firm specific inefficiency estimate from the maximum likelihood estimation. The restrictions imposed by the model often lead to various parameter values.

Testing the robustness of the estimated frontier function is often done using the loglikelihood ratio test. This test shows the relevance or otherwise of the inefficiency component. A null hypothesis of no inefficiency in the observed sampled units $\left(H_{0}: \mu=0\right)$ is usually tested against an alternative hypothesis $\left(H_{1}: \mu>0\right)$. If the test favours the null hypothesis, then the stochastic frontier model is reduced to an OLS model with normal errors.

\section{The Empirical Model}

We specified a cost function using the Cobb-Douglas functional form as used in previous studies (Oteng-Abayie et al., 2011; Hasan, Kamil, Mustafa \& Baten, 2012). Despite its known limitations, this functional form had an advantage in identifying growth patterns in the microfinance sector and it is simple in handling multiple inputs (Murthy, 2002). The translog functional form, though widely applied in the literature, has the tendency to exhibit near-multicollinearity due to the different output variables used (Farsi \& Filippini, 2004). Mitchell \& Onvural (1996) with robust estimations show that cost function does not clearly have a translog form in the banking industry. Translog specifications have also been found to result in overestimation of cost inefficiencies. Berger \& Deyoung (1996) in their study of inefficiency in US banks found that more than 50 percent of costs were overestimated by the translog model. Besides these limitations, our initial test estimation using both Cobb-Douglas and translog specifications revealed that the Cobb-Douglas better fits the available data set ${ }^{19}$.

19. The OLS residuals estimated from the translog function to serve as starting values for the Maximum likelihood estimation did not have the right skewness. 
Cost efficiency reflects the closeness of the real costs of an MFI to that of 'best practice' firms in situations where identical outputs are produced under the same conditions (Hermes et al., 2009). Following the intermediation approach, we estimated the cost function below:

$$
\begin{aligned}
& \operatorname{InTC} C_{i t}=\beta_{0}+\beta_{1} \operatorname{InSAL} L_{i t}+\beta_{2} \operatorname{InR}_{i t}+\beta_{3} \operatorname{InGLP} P_{i t}+\beta_{4} \operatorname{InNAB} B_{i t}+\beta_{4} \operatorname{In} L L P_{i t}+ \\
& \beta_{4} \operatorname{InN} L O_{i t}+V_{i t}+U_{i t}
\end{aligned}
$$

where

$\mathrm{TC}=$ Total cost faced by the institution and is proxied as the total expenses to total assets ratio multiplied by the total assets (US\$) ${ }^{20}$.

$\mathrm{SAL}=$ Price of one unit of labour per year and is calculated as the operating expenses to total assets ratio multiplied by the total assets (US\$).

$\mathrm{R}=$ Interest payments per deposits held. It is proxied as the financial expenses to total assets ratio divided by the total deposits to total assets ratio.

GLP $=$ Gross loan portfolio, total outstanding loans including current, delinquent and rescheduled loans, but excludes loans written off and interests receivable.

$\mathrm{NAB}=$ Number of active borrowers, the total number of clients actively accessing financial services at a given point in time

LLP = Loan loss provision, the percentage of the loan portfolio set aside against loan defaults based on cash flow

NLO = Number of loan officers, the total number of employees directly involved in managing the loan portfolio

$V_{i t}=$ Random disturbance term that captures the effects of random factors and measurement errors, and

$U_{i t}=$ the inefficiency term.

From the cost function equation, SAL, R, and NLO are inputs while GLP, NAB, and LLP are outputs. All variables were taken in logs.

Computed ratios obtained from equation (5) are then regressed on firm-specific control variables to capture the factors that influence the efficiency of MFIs in SSA. The inefficiency model estimated is specified as:

20. The variables TC, SAL, R and GLP do not have data directly available from the MIX market data source. The available data is in the form of ratios such as total equity to total assets. That explains why we multiply these ratios with total assets to construct data for TC, SAL, R and GLP. 
$U_{i t}=f(C P B, P A R, A L B, P F B, B S M, T A, R O A, O E A, Y L D, A G E)$

where

$U_{i t}=$ the level of individual firm inefficiency

$\mathrm{CPB}=$ Cost per borrower, measured as the ratio of operating expenses to an average number of active borrowers. A good proxy for service delivery and we expect it to relate negatively to efficiency.

$\mathrm{PAR}=$ Portfolio at risk, measures the quality of MFI's assets that are at risk past 30 days due. Higher values indicate poor loan collection and inefficient operations.

$\mathrm{ALB}=$ Average loan balance per borrower (in US dollars), measures depth of outreach and calculated as total loans divided by the number of active borrowers. The coefficient can be positive or negative.

$\mathrm{PFB}=$ Percentage of female borrowers, measures breadth of outreach and calculated as the proportion of female borrowers to the total number of active borrowers. The coefficient can be positive or negative.

$\mathrm{TA}=$ Total assets, measures MFI Size. Larger size firms benefit from scale economies and are more likely to be cost efficient in operations. We expect TA to relate positively to efficiency.

ROA $=$ Return on assets, measures profitability and sustainability of MFIs. Profitable MFIs are more likely to be efficient in their operations so we expect a positive relationship.

$\mathrm{BSM}=$ Borrower per staff member, measures MFI staff productivity and performance. Improved staff performance will lead to increased efficiency in operations; hence, we expect a positive impact.

YLD = Yield on the gross portfolio, a proxy for interest rate charged by MFIs to clients and the cost of borrowing. We expect a positive relation.

AGE = Age of MFI, the number of complete years of operation of MFI since establishment. MFIs often become efficient over time so we expect AGE to be positively related to MFI efficiency due to learning curve effects.

Estimation of equations (5) and (6) was done simultaneously in a one-step approach as proposed by Battese \& Coelli (1995) following the maximum likelihood procedure. 


\section{Data Sources}

The data for this study came from the MixMarket ${ }^{\mathrm{TM}}$, a global web-based microfinance information platform that captures MFI activities. The study covered ten countries ${ }^{21}$ and selection was done purposively based on the level of microfinance activities and data availability, since reporting to the database is not obligatory for MFIs. The total number of MFIs reporting to the database during the study period (2003-2013) for the 10 countries considered was 378 . However, to ensure quality data, MFIs with incomplete data as well as those rated below three diamonds were excluded from the final sample. The data used covered 71 MFIs in 10 countries for 10 years with a total of 619 observations. Though the database has the limitation of not capturing all MFIs globally, it is currently the best available data source on microfinance.

\section{Results and Discussions}

The maximum likelihood estimates of the stochastic cost frontier model are presented in Table 1. Computation was done using the statistical software programme, LIMDEP version 10. Most coefficients estimated ( 83 percent) are significant with the expected signs.

We ran six separate regression models that simultaneously estimate the cost efficiency levels of the sampled MFIs and the factors that explain inefficiency. From Table 1, model [1] serves as the base model for the cost function estimated. Model [2] captures the effects of size and profitability on MFI efficiency. Large size firms are often said to enjoy economies of scale and are therefore more likely to be profitable and efficient in operation. Model [3] includes both depth and breadth of outreach variables to capture their influence on efficiency. Efficient MFIs as argued should have greater outreach to clients. The evidence here suggests that serving poorer and marginalised populations impede efficient operations. Model [4] examines MFI cost side variables to capture their influence on the efficiency level. Firms operating at a higher cost are less likely to be efficient. Model [5] includes risk and productivity variables to examine their influence on efficiency. The higher risk associated with making loans is often cited as a reason for the high interest rates charged by institutions. The empirical evidence shows that untimely recovery of loans drives MFI inefficiency. Finally, model [6] combines all the models, including the age of the institutions, to evaluate the robustness of the results. All discussions on the variance parameters are based on model [1] since the results remain robust even after incorporating additional variables. Panel A of Table 1 reports the results from the cost frontier estimation while panel B presents the results of the determinants of inefficiency.

21. Ghana, South Africa, Kenya, Tanzania, Uganda, Burkina Faso, Benin, Ethiopia, Cameroon and Nigeria. 
Table 1: Maximum likelihood estimates of cost efficiency and correlates of inefficiency (dependent variable $=\mathrm{TC}$ )

\begin{tabular}{|c|c|c|c|c|c|c|}
\hline \multirow[t]{2}{*}{ Variables } & \multicolumn{6}{|c|}{ Estimated Models } \\
\hline & {$[1]$} & {$[2]$} & [3] & {$[4]$} & {$[5]$} & [6] \\
\hline \multicolumn{7}{|l|}{ Panel A } \\
\hline SAL & $\begin{array}{l}0.73641^{* * *} \\
(85.56)\end{array}$ & $\begin{array}{l}0.69368^{* * *} \\
(89.52)\end{array}$ & $\begin{array}{l}0.71069^{* * *} \\
(31.06)\end{array}$ & $\begin{array}{l}0.73343^{* * *} \\
(68.43)\end{array}$ & $\begin{array}{l}0.71935^{* * *} \\
(82.57)\end{array}$ & $\begin{array}{l}0.73792^{* * *} \\
(64.98)\end{array}$ \\
\hline $\mathrm{R}$ & $\begin{array}{l}0.04927^{* * *} \\
(4.74)\end{array}$ & $\begin{array}{l}0.06474^{* * *} \\
(4.88)\end{array}$ & $\begin{array}{l}0.02055 \\
(0.86)\end{array}$ & $\begin{array}{l}0.03717^{* * *} \\
(5.13)\end{array}$ & $\begin{array}{l}0.06113^{* * *} \\
(4.42)\end{array}$ & $0.01603^{*}(1.93)$ \\
\hline GLP & $\begin{array}{l}0.31024^{* * *} \\
(10.81)\end{array}$ & $\begin{array}{l}0.22428^{* * *} \\
(8.18)\end{array}$ & $\begin{array}{l}0.55507^{* * *} \\
(8.05)\end{array}$ & $\begin{array}{l}0.30825^{* * *} \\
(11.45)\end{array}$ & $\begin{array}{l}0.27280^{* * *} \\
(9.93)\end{array}$ & $0.32815^{* * *}(11.38)$ \\
\hline NAB & $\begin{array}{l}-0.02378 \\
(-0.43)\end{array}$ & $\begin{array}{l}0.02211 \\
(0.42)\end{array}$ & $\begin{array}{l}0.02504 \\
(0.13)\end{array}$ & $\begin{array}{l}0.10421^{*} \\
(1.75)\end{array}$ & $\begin{array}{l}0.01212 \\
(0.22)\end{array}$ & $\begin{array}{l}0.01899 \\
(0.31)\end{array}$ \\
\hline LLP & $\begin{array}{l}0.03226^{* *} \\
(2.13)\end{array}$ & $\begin{array}{l}0.01471 \\
(0.92)\end{array}$ & $\begin{array}{l}0.02981 \\
(0.90)\end{array}$ & $\begin{array}{l}0.06983^{* * *} \\
(5.13)\end{array}$ & $\begin{array}{l}0.01631 \\
(1.13)\end{array}$ & $0.03529^{*}(1.80)$ \\
\hline NLO & $\begin{array}{l}-0.04604 \\
(-1.14)\end{array}$ & $\begin{array}{l}-0.05158 \\
(-1.18)\end{array}$ & $\begin{array}{l}0.11415 \\
(0.76)\end{array}$ & $\begin{array}{l}0.01208 \\
(0.28)\end{array}$ & $\begin{array}{l}-0.03823 \\
(-0.79)\end{array}$ & $\begin{array}{l}0.02802 \\
(0.59)\end{array}$ \\
\hline Constant & $\begin{array}{l}0.62612^{* * *} \\
(4.47)\end{array}$ & $\begin{array}{l}-312.140 \\
(0.03)\end{array}$ & $\begin{array}{l}-0.88767^{* * *} \\
(-3.01)\end{array}$ & $\begin{array}{l}0.41024^{* * *} \\
(3.66)\end{array}$ & $\begin{array}{l}-227.4773 \\
(-0.05)\end{array}$ & $0.48817^{* * *}(4.18)$ \\
\hline \multicolumn{7}{|c|}{ Panel B: Inefficiency Model } \\
\hline $\mathrm{TA}$ & & $\begin{array}{l}0.54007^{* * *} \\
(7.91)\end{array}$ & & & & $\begin{array}{l}0.80932^{* * *} \\
(6.84)\end{array}$ \\
\hline ROA & & $\begin{array}{l}0.03042 \\
(0.04)\end{array}$ & & & & $\begin{array}{l}0.60407 \\
(1.26)\end{array}$ \\
\hline ALB & & & $\begin{array}{l}-0.00178^{* * *} \\
(-72.01)\end{array}$ & & & $\begin{array}{l}-0.00059^{* * *} \\
(-4.34)\end{array}$ \\
\hline PFB & & & $\begin{array}{l}-6.03330 \\
(1.91)\end{array}$ & & & $\begin{array}{l}-0.78980^{* * *} \\
(-3.03)\end{array}$ \\
\hline $\mathrm{CPB}$ & & & & $\begin{array}{l}0.00338 \\
(1.21)\end{array}$ & & $\begin{array}{l}-0.00037 \\
(-1.12)\end{array}$ \\
\hline OEA & & & & $\begin{array}{l}1.41001 \\
(0.66)\end{array}$ & & $\begin{array}{l}1.51869^{* * *} \\
(4.58)\end{array}$ \\
\hline BSM & & & & & $\begin{array}{l}-0.00088 \\
(-1.13)\end{array}$ & $\begin{array}{l}-0.00477^{* * *} \\
(-4.36)\end{array}$ \\
\hline YLD & & & & & $\begin{array}{l}-0.09992 \\
(-0.31)\end{array}$ & $\begin{array}{l}-0.16757 \\
(-0.72)\end{array}$ \\
\hline PAR & & & & & $\begin{array}{l}-0.89759^{* *} \\
(-2.16)\end{array}$ & $\begin{array}{l}0.23364 \\
(0.62)\end{array}$ \\
\hline AGE & & & & & & $\begin{array}{l}0.02210 \\
(1.41) \\
\end{array}$ \\
\hline Constant & $\begin{array}{l}0.62612^{* * *} \\
(4.47)\end{array}$ & $\begin{array}{l}310.689 \\
(0.03)\end{array}$ & $\begin{array}{l}2.51154^{* * *} \\
(12.92)\end{array}$ & $\begin{array}{l}-1.15464 .22 \\
(-0.53) \\
\end{array}$ & $\begin{array}{l}9.6664 \\
(0.05)\end{array}$ & $-4.32355^{* * *}(-4.99)$ \\
\hline $\operatorname{Lambda}(\lambda)$ & $\begin{array}{l}4.36494^{* * *} \\
(110.89)\end{array}$ & $\begin{array}{l}0.96395^{* * *} \\
(14.15)\end{array}$ & $\begin{array}{l}0.73781^{* * *} \\
(8.44)\end{array}$ & $\begin{array}{l}3.11809^{* * *} \\
(18.24)\end{array}$ & $\begin{array}{l}1.63144^{* * *} \\
(31.44)\end{array}$ & $0.68435^{* * *}(6.14)$ \\
\hline Sigma (u) & $\begin{array}{l}1.25676^{* * *} \\
(3.35)\end{array}$ & $\begin{array}{l}0.26104^{* * *} \\
(60.18)\end{array}$ & $\begin{array}{l}0.48845^{* * *} \\
(8.68)\end{array}$ & $\begin{array}{l}0.94947^{*} \\
(1.72)\end{array}$ & $\begin{array}{l}0.44364^{* * *} \\
(31.17)\end{array}$ & $0.22561^{* * *}(33.60)$ \\
\hline $\operatorname{Eta}(\eta)$ & $\begin{array}{l}-0.03877^{* * *} \\
(-14.19)\end{array}$ & $\begin{array}{l}-0.00019 \\
(-0.03)\end{array}$ & $\begin{array}{l}-0.41252^{* * *} \\
(-3.34)\end{array}$ & $\begin{array}{l}-0.03027^{* * *} \\
(-6.43)\end{array}$ & $\begin{array}{l}-0.00024 \\
(0.05)\end{array}$ & $\begin{array}{l}-0.04149^{* * *} \\
(-6.30)\end{array}$ \\
\hline
\end{tabular}

Source: Estimation

Significance Level: ${ }^{* * *},{ }^{* *}$, and ${ }^{*}$ at 1 percent, 5 percent and 10 percent respectively 
NOTE: Detail parameters for the base model [1]: $\gamma=0.89722 ; \sigma=1.28932, \sigma_{v}=0.28972, \sigma_{u}^{2}=$ 0.08290, $\sigma_{v}^{2}=1.57946$. Log-likelihood $=-380.53$; Wald Chi2 (6) $=306.6$; Prob $>$ Chi2 $=0.0000$.

The inefficiency parameter $(\lambda)$ is significant in all the models, suggesting the existence of inefficiency among the sampled MFIs. The null hypothesis of 'no inefficiency among the sample MFIs observed' over the period is therefore rejected in favour of the alternative hypothesis. Eta ( $\eta$, which is the parameter for time varying inefficiency, is significant in four out of the six models estimated. The coefficient of the parameter $(\eta)$ is negative in all model specifications which show that cost inefficiency of MFIs increases over time. For managers of MFIs, this is both bad news and a wake-up call to tackle the incidence of rising cost in the industry. The total variance, $\sigma^{2}=0.83118$ points to a wide variation in cost of MFIs due to differences in cost efficiencies. It shows the goodness of fit and appropriateness of the distributional assumptions made regarding the error term.

From panel A, with the exception of NLO and probably NAB, all other variables included in the models are significant. NLO is not significant in any of the models, assuming both positive and negative coefficients. Similarly, NAB though with a positive coefficient is only significant in the model [4]. The variables SAL, R and GLP have positive coefficients as expected and are statistically significant in all six models. A positive coefficient suggests an outward shift in the cost function and hence higher cost. The variable LLP, which captures the risk-taking strategies of MFIs had a positive coefficient and is statistically significant in three of the models estimated, indicating that MFI risk strategy has an effect on the cost frontier. A significantly positive coefficient, therefore, means an increase in such a variable will result in increased cost efficiency of MFIs (reduction in cost inefficiency).

The sum of the coefficients of all variables in Model [1] is 1.058 which shows a constant cost to size, indicating the existence of growth potential of the microfinance industry in SSA. The results show that personnel costs (SAL) constitute the greater proportion (6973 percent) of the operational cost of MFIs included in the study. This finding compares favourably with that of Oteng-Abayie et al. (2011) who find the operating cost of MFIs in Ghana to be 66 percent. These higher operating costs which plaque industry operations is one reason for the consistent negative returns enjoyed by firms in SSA relative to other regions, hence, less efficient in operations. The nature of the operating environment which is largely seen us 'business unfriendly' could also account for this coupled with regulatory and governance issues. The high cost of service delivery naturally implies limited outreach to poorer clients requiring crucial financial products and services.

Interest payments made by MFIs on loans is one component of their costs and is linked to efficiency. The results show that interest payments significantly drive the cost of operation of MFIs in the region. The magnitude is, however, low and variable (less than 
seven percent) of the total cost compared with 18 percent reported by Oteng-Abayie et al. (2011) for Ghana. This could be attributed to the effects of regulation on deposit taking which prohibits unregulated MFIs from collecting deposits. Since most MFIs in SSA are non-profit and member-based organisations with a dominant social mission, little priority is placed on interest payments. Similarly, the results show that GLP accounts for 22 percent to 55 percent of the total cost faced by MFIs. This reflects the small size nature of most firms in the industry. A small loan portfolio suggests less outreach even in the absence of mission drift. The average loan loss provision (LLP) of 3.3 percent can be said to be high compared with the 0.8 percent reported for the region (CGAP, 2010) and the agreed industry standard of two percent. This point to the need for MFIs to improve on loan collection efforts and method as the current recovery cost appears to drive down efficiency.

Panel B of Table one presents the results of the inefficiency model which captures the main sources of variation. The coefficient of ALB is negative and significant as expected, signalling that MFIs with lower average loan balances (lending to the poor) are less efficient. This finding confirms that of Hermes et al. (2009) but contradicts that of Mersland \& Strom (2010) who find the occurrence of mission drift due to portfolio diversification as MFIs grow older and larger. The breadth of outreach variable (PFB) had a negative coefficient and is statistically significant in the final model. This suggests that augmenting lending to more women will lead to increased cost inefficiency in MFI operation, a finding consistent with Hermes et al. (2009).

Total assets (TA) had a positive coefficient and are statistically significant, suggesting that as the asset base of an MFI increases, its cost efficiency level improves. Thus, larger firms in the industry have cost advantages and may be enjoying economies of scale. This result contradicts Segum \& Anjugam (2013) who found negative impacts of MFIs assets on efficiency in SSA. The coefficient for ROA is positive but statistically insignificant. This result is consistent with that of Wijesiri, Vigano \& Meoli (2015) and Lobovics, Hermes \& Hudon (2014) who find ROA not to have a significant impact on MFI social efficiency in Sri Lanka and Vietnam respectively. ROA also gives some insights into MFI sustainability (Mersland \& Strom, 2008) and the insignificant effects on cost efficiency may be attributed to the use of unadjusted measures of profitability in the study.

Furthermore, the financial management and performance factors included as explanatory variables are found to have effects on cost efficiency. The yield on gross portfolio (YLD) is statistically insignificant with negative effects on MFI cost efficiency. This goes contrary to our expectation. The coefficient for borrower per staff member (BSM) is negative but significant only in Model [6]. This means that increased staff productivity has positive cost benefits to the institutions. The need for MFIs to evaluate the kind of training programmes conducted for staff appears vital as it impacts on 
financial performance. Also, the operating expenses incurred in building a unit of the asset (OEA) had a positive and statistically significant coefficient. Higher operating costs, therefore, manifests in the inefficient cost of service delivery by MFIs.

Moreover, the importance of training and experience has been conceptualised to have positive impacts on MFIs performance. The positive coefficient for age means that inefficiency deteriorates as MFIs grow. However, the insignificance of the variable suggests that learning curve effects have no impact on MFI efficiency. This result supports previous evidence by (Oteng-Abayie et al., 2011) that documents the positive impacts of age on MFI performances, but contradicts that of Hermes et al. (2009) who found younger firms leapfrogging older institutions in terms of efficiency in operations.

The overall distribution of economic efficiency scores for the period 2003 to 2013 is captured in Table 2. The minimum and maximum efficiency range from 7.4 percent to 94 percent respectively with a mean average score of 40.9 percent. This implies that the sampled MFIs exhibit wide variation in inefficiency in their operations. The ratio of the variation due to inefficiency to the total variation () shows that 89.7 percent of the variation in the level of total cost is due to inefficiency. The average economic efficiency score shows that on average MFIs can reduce costs by 59.1 percent and still produce the same level of output by improving on their technical and allocative efficiency performances. Nonetheless, average MFIs could save 56.48 percent costs [1 - (40.9/94)] if they were to follow 'best practices' and operate at the level attained by the most cost efficient units within the sample. The observed inefficiency support previous finding by Oteng-Abayie et al. (2011). The efficiency score distribution revealed that 74.96 percent of MFIs had scores below 50, with only 24.33 percent scoring above this mark. Only 4.83 percent of MFIs had scores above 90 which can be said to be operating near efficiency levels. Inefficiency, therefore, exists due to management differences among the chosen firms. 
Table 2: Distribution of efficiency scores from cost function

\begin{tabular}{|l|l|l|}
\hline Efficiency Score & Frequency & Percentage (\%) \\
\hline Less than 10 & 5 & 0.80 \\
\hline $10-20$ & 61 & 9.83 \\
\hline $20-30$ & 123 & 19.83 \\
\hline $30-40$ & 146 & 23.54 \\
\hline $40-50$ & 130 & 20.96 \\
\hline $50-60$ & 88 & 14.19 \\
\hline $60-70$ & 17 & 2.74 \\
\hline $70-80$ & 2 & 0.32 \\
\hline $80-90$ & 14 & 2.25 \\
\hline Above 90 & 30 & 4.83 \\
\hline Mean & & 0.4095059 \\
\hline Standard deviation & & 0.1862572 \\
\hline Minimum & & 0.0742533 \\
\hline Maximum & & 0.9400140 \\
\hline Sorce:Estimation & & \\
\hline
\end{tabular}

Source: Estimation

Figure 1 depicts the kernel density plots of the inefficiency estimates while Figure 2 illustrates the year-wise average cost efficiency of MFIs. The average efficiency estimate for the whole industry for the study period shows that MFIs achieved 40.9 percent cost efficiency in their fund's intermediation activities compared with best-practiced MFIs operating in the same environment. The highest cost efficiency was in 2004 (45.28 percent) but after that, the industry witnessed a steady decline up to the year 2013. This finding is in sharp contrast with that of Hassan \& Sanchez (2009) who found declining levels of MFI efficiency for the period 2001-2005 in Latin America, the Middle East and North Africa (MENA), and South Asia countries. Though the average cost efficiency has been on the decline for the industry the proportional change over the years has been variable. For instance, the cost efficiency change for 2006 to 2007 was 0.7 percent compared with that of 2007 to 2008 which was 1.5 percent. The year-wise average cost efficiency, though on the decline, seemed to fluctuate during the study period.

Figure 3 shows the relationship between the year-wise mean efficiency of MFIs as against the loan loss provisioning made by MFIs over the same period. The graph re-enforces the results of the study. Thus, as the mean efficiency level of MFIs decline over the years, their cost of operation increases, making the firms less cost efficient. This is a pointer to managers of MFIs to take proactive steps and improve on their loan recovery efforts and general management. 


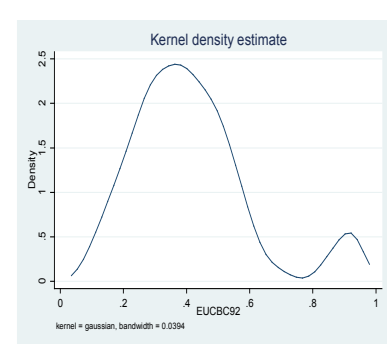

1)

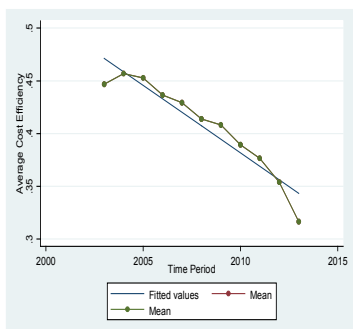

2)

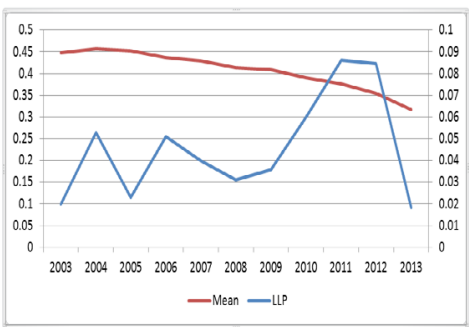

3)

Figure 1: Kernel density estimates for inefficiencies from the time-dependent model. Figure 2: Year-wise average cost efficiency of MFIs in SSA. Figure 3: Relationship between MFIs mean efficiency and loan loss provision.

\section{Conclusion and Recommendations}

This study applied the SFA to investigate cost efficiency of MFIs in SSA and the factors that influence inefficiency using a sample of 619 observations for the period 2003 to 2013. We find convincing evidence that inefficiency exists in the operations of MFIs as the institutions currently achieve a 40.9 percent level of cost efficiency. This gives an indication that substantial cost reduction possibilities exist which firms need to exploit by improving their management strategies. A wide variation also exists among firms which reflect the diverse nature of MFIs in the industry. While some firms achieved a 94 percent level of efficiency, the majority (74.96 percent) of firms were found at the low end of the efficiency scale with efficiency scores below 50 percent. Subsidies could have played a role in this outcome since our analysis pooled firms together without accounting for subsidy levels received. The year-wise average cost efficiency calculations showed that MFI efficiency levels have been declining since 2004, which has implications for industry sustainability.

In the efficiency model estimation, the significance of SAL, R, and GLP in all the models estimated provides support for the assertions that operating costs of MFIs are too high and that for these institutions to attain sustainability and efficiency levels, commercialisation is necessary. As pointed out by Hermes et al. (2009), commercialisation may induce MFI efficiency. The high average loan loss provision of 3.3 percent observed lend further support on the need for firms to re-examine their risktaking strategies and improve on loan collections.

The main factors influencing MFI efficiency are the size of the institution, outreach variables, cost factors and those related to risk management. Total assets (TA) and operating expenses to assets ratio (OEA) positively and significantly influence MFI 
efficiency. This shows the effect of size in attaining cost efficiency and also highlights the cost advantages arising from economies of scale as noted in both theoretical and empirical works. We find that MFIs outreach depth is significant and negatively related to cost efficiency as expected. This shows that serving the poor and reaching out to the marginalised has greater cost implications to institutions. The high cost involved in administering small loans over geographically dispersed locations is the reason for this observed inefficiency in outreach. This further explains why most profit-oriented MFIs prefer to operate in the cities at the expense of rural areas. We also find that focusing on women is more cost efficient. This has a policy implication for balanced social development. Furthermore, the negative and significant result for staff productivity (BSM) points to the need for MFIs to invest in staff development through training programmes and offer incentives aimed at enhancing productivity and cost-efficient operations. The determinants of MFI efficiency in SSA therefore in our analysis are TA, ALB, PFB, OEA, and BSM.

A number of recommendations emerge from our results. Firstly, practitioners and managers of MFIs should improve on technical training in the area of portfolio quality and offer diverse financial services and products innovatively so as to minimise the cost of operations and enhance efficiency. Secondly, other cost control measures such as effective loan collection and client screening for loans need to be jointly pursued by management as well as focusing on staff welfare issues for enhanced productivity. Finally, efforts should be made to transform institutions currently not taking deposits to be deposit-accepting institutions since this serves as a relatively cheap source of funds for organisations and could help reap positive size effects and address funding constraints. 


\section{References}

Abate, G. T., Borzaga, C. and Getnet, K. (2014). Cost-efficiency and outreach of microfinance institutions: Trade-offs and the role of ownership. Journal of International Development, 26, pp. 923-932.

Adhilkary, S. and Papachristou, G. (2014). Is there a trade-off between financial performance and outreach in South Asia microfinance institutions? The Journal of Developing Areas, 48 (4), pp. 381-402.

Aigner, D., Lovell, C. A. K. and Schmidt, P. (1977). Formulation and estimation of stochastic frontier production function models. Journal of Econometrics, 6, pp. 2137.

Amersdorffer, F., Buchenrieder, G., Bokusheva, R. and Wolz, A. (2015). Efficiency in microfinance: Financial and social performance of Agricultural Credit Cooperatives in Bulgaria. Journal of the Operational Research Society, 66, pp. 57-65.

Ayayi, A. G. and Sene, M. (2010). What drives microfinance institution's financial sustainability. The Journal of Developing Areas, 44 (1), pp. 303-324.

Balkenhol, B. (2007). Microfinance and Public Policy: Outreach Performance and Efficiency. ILO.

Barth, J. R., Lin, C., Ma, Y., Saede, J. and Song, F. M. (2013). Do Bank regulation, supervision and monitoring enhance or impede Bank efficiency? Journal of Banking and Finance, 37, pp. 2879-2892.

Bateman, M. (2011). Microfinance as a development and poverty reduction policy: Is it everything it's cracked up to be? ODI Background Note. London: Overseas Development Institute

Battase, G. E. and Coelli, T. J. (1995). A model for technical inefficiency effects, a stochastic frontier function for panel data. Empirical Economics, 20.

Berger, A. N. and DeYoung, R. (1997). Problem loans and cost efficiency in Commercial Banks. Journal of Banking and Finance, 21, pp. 849-870.

Bhatt, N. and Tang, S. Y. (2001). Delivering microfinance in developing countries: Controversies and policy perspectives. Policy Studies Journal, 29 (2), pp. 319-333.

Bos, J. W. B. \& Millone, M. (2014). Practice what you preach: Microfinance business models and operational efficiency. World Development, 70, pp. 28-42. 
Conning, J. (1999). Outreach, sustainability and leverage in monitored and peer monitored lending. Journal of Development Economics, 60 (1), pp. 51-77.

Farrell, M. J. (1957). The Measurement of productive efficiency. Journal of Royal Statistical Society, 120, pp. 253-29o.

Farsi, M. and Filippini, M. (2004). Regulation and measuring cost efficiency with panel data models: Application to electricity distribution utilities. Review of Industrial Organization, 25, pp. 1-19.

Glass, J. C., McKillop, D. G. and Rasaratnam, S. (2009). Irish Credit Union: Investigating performance determinants and the opportunity cost of regulatory compliance. Journal of Banking and Finance, 34, pp. 67-76.

Guha, B. and Chowdhury, P. R. (2013). Microfinance competition: Motivated microlenders, double-dipping and default. Journal of Development Economics, 105, pp. 86102.

Gutierrez-Nieto, B., Serrano-Cinca, C. and Malinero, C. M. (2007). Microfinance institutions and efficiency. The International Journal of Management Sciences, Omega, 35 (2), pp.131-142.

Gutierrez-Nieto, B., Serrano-Cinca, C. and Molinero, C. M. (2009). Social efficiency in microfinance institutions. Journal of the Operational Research Society, 60 (1), pp. 104-119.

Haq, M., Skully, M. and Pathan, S. (2010). Efficiency of microfinance institutions: A data envelopment analysis. Asian-Pacific Financial Markets, 17 (1), pp. 63-97.

Hasan, M. Z., Kamil, A. A., Mustafa, A. and Baten, A. B. (2012). Stochastic frontier model approach for measuring stock market efficiency with different distributions. PLOS ONE 7 (5), e37047.

Hassan, M. K. and Sanchez, B. (2009). Efficiency analysis of microfinance institutions in developing countries. Working Paper No 2009-WP-12, Networks Financial Institute, Indiana State University.

Helms, B. (2006). Access for life: building inclusive financial systems. Washington, DC: World Bank.

Hermes, N., Lensink, R. and Meesters, A. (2009). Financial development and the efficiency of microfinance institutions. Online resource available at http://papers. ssr.com/sol3/papers.cfm. 
Hermes, N., Lensink, R. and Meesters, A. (2011). Outreach and efficiency of microfinance institutions. World Development, 39 (6), pp. 938-948.

Honohan, P. (2008). Cross-country variation in household access to financial services. Journal of Banking and Finance, 32 (11), pp. 2493-2500.

Imai, K. S., Gaiha, R., Thepa, G., Annim, S. K., \& Gupta, A. (2012). Financial performance of microfinance institutions: A macroeconomic and institutional perspective. Discussion Paper Series, DP 2012-04, Research Institute of Economics and Business Administration, Kobe University.

Jondrow, J., Lovell, C., Materov, I. and Schmidt, P. (1982). On the estimation of technical inefficiency in the stochastic frontier production function model. Journal of Econometrics, 19, pp. 233-238.

Lafuorcade, A., Isern, I., Mwangi, P. and Brown, M. (2005). Overview of the outreach and financial performance of microfinance institutions in Africa. MIX and CGAP, Washington DC.

Lebovics, M., Hermes, N. and Hudon, M. (2014). Are financial and social efficiency mutually exclusive? A case study of Vietnamese microfinance institutions. Working Paper No. 14/oo9, Centre Emile Bernheim, Solvay Business School, CEB.

Meeusen, W. and van den Broeck, J. (1977). Efficiency estimation from Cobb-Douglas production functions with composed error. International Economic Review, 18, pp. 435-444.

Mersland, R. and Strom, R. O. (2008). Performance and trade-offs in microfinance organization: does ownership matter? Journal of International Development, 20 (5), pp. 598-612.

Mersland, R. and Strom, R. O. (2009). Performance and governance in microfinance institutions. Journal of Banking and Finance, 33 (3), pp. 662-669.

Mersland, R. and Strom, R. O. (2010). Microfinance mission drift? World Development, 38 (1), pp. 28-36.

Mersland, R., Randoy, T. and Strom, R. O. (2011). The impact of international influence on microbanks performance: a global survey. International Business Review, 20, pp. $163-176$.

Mitchell, K. and Onvural, N. M. (1996). Economics of scale and scope at large Commercial Banks: Evidence from the Fourier flexible functional form. Journal of Money, Credit and Banking, 28 (2), pp.178-199 
Murthy, K. V. B. (2002). Arguing a case for Cobb-Douglas production function. Review of Commerce Studies, 20-21(1), pp. 75-91.

Nawaz, A. (2009). Efficiency and productivity of microfinance: Incorporating the role of subsidies. Ph.D. Dissertation, University of Gottingen, Germany.

Nghiem, H., Coelli, T. and Rao, D.S. P. (2006). The efficiency of microfinance in Vietnam: Evidence from NGO schemes in the North and the Central Regions. International Journal of Environmental, Cultural, Economic and Social Sustainability, 2 (5), pp.71-78.

Oteng-Abayie, E. F., Amanor, K. \& Frimpong, J. M. (2011). The measurement and determinants of economic efficiency of microfinance institutions in Ghana: A stochastic Frontier Approach. African Review of Economics and Finance, 2 (2), pp. 149166.

Pitt, M. and Lee, L. (1981). Measurement and sources of technical inefficiency in the Indonesian weaving industry. Journal of Development Economics, 9, pp. 43-64.

Rhyne, E. and Otero, E. (2006). Microfinance through the next decade: visioning the who, what, where, when and how. Paper Commissioned by the Global Microcredit Summit 2006, Boston MA: ACCION International.

Rojas-Suarez, L. (2007). The provision of banking services in Latin America: Obstacles and recommendations. Working Paper No. 124, Centre for Global Development.

Schmidt, P. and Sickles, R. C. (1984). Production functions and panel data. Journal of Business and Economic Statistics, 2(4), pp. 367-374.

Seale, Jr. J. L. (1990. Estimated stochastic frontier system with unbalanced panel data: the case of floor tile manufacturers in Egypt. Journal of Applied Econometrics, 5, pp. 59-74.

Segun, K. R. S. and Anjugan, M. (2013). Measuring the efficiency of Sub-Saharan Africa's microfinance institutions and its drivers. Annals of Public Cooperative Economics, 84 (4), pp. 399-422.

Serrano-Cinca, C., Gutierez-Nieto, B. and Reyes, N. M. (2015). A social and environmental approach to microfinance credit scoring. Journal of Cleaner Production, 112 (4), pp. 3504-3513.

Simar, L. and Wilson, P. A. (1998). Sensitivity analysis of efficiency scores: how to bootstrap in nonparametric frontier models. Management Science, 44, pp. 49-61. 
Simar, L. and Wilson, P.A. (2000). A general methodology for bootstrapping in nonparametric frontier models. Journal of Applied Statistics, 27, pp.779-802.

Singhdu, s., Goyaldu, s. K. and Shrmadu, s. K. (2013). Technical efficiency and its determinants in microfinance institutions in India: A firm level analysis. Journal of Innovation Economics and Management, 1(11), pp. 15-31.

Tabak, B. M., Fazio, D. M. and Cajueiro, D. O. (2012). The relationship between Banking market competition and risk-taking: do size and capitalization matter? Journal of Banking and Finance, 36, pp. 3366-3381.

Valverde, S., Humphrey, D. and del Paso, R. (2007). Opening the black box: finding the sources of cost inefficiency. Journal of Productivity Analysis, 27, pp. 209-220.

Wijesiri, M., Vigano, L. and Meoli, M. (2015). Efficiency of microfinance institutions in Sri Lanka: A two-stage double bootstrap DEA approach, Economic Modelling, 47, pp. $74-83$.

Wilson, P.W. (2008). FEAR: A software package for frontier efficiency analysis with R. Socio-Economic Planning Sciences, 42, pp. 247-254.

Worthington, A. C. (2000). Cost efficiency in Australian Local Government: A comparative analysis of mathematical programming and econometrical approaches. Financial Accounting and Management, 16(3), pp. 2001-223. 